UDK 070:81'38

82-92

doi: $10.5937 /$ bastina31-35585

Originalni naučni rad

\author{
Dragan Lj. TANČIÍ́ \\ Institute of Serbian Culture Priština - Leposavić
}

Adela ČOLIĆ**

Lidija D. TANČIĆ ${ }^{* * *}$

\title{
THE PROBLEMS OF SCIENTIFIC DEFINITION AND CLASSIFICATION OF GENRES IN THE SCIENTIFIC FUND****
}

\begin{abstract}
Problems of scientific definition and redefinition of terms, consequently, in accordance with the topic of this scientific paper, are also problems of scientific definition of the term genre and classification of genres in the scientific fund. Defining the term genre is an important scientific-cognitive process, that acquires the essential determinants of the term itself, which have a definiendum and definiens; subject and content value, which includes the whole subject and especially the criteria for classification of the term. In this paper, genetic definitions will include the genesis and development of the concept of genre and scientific-theoretical and methodological directions of various sciences and scientific disciplines. According to temporal and territorial determinants, this paper covers a closer scientific-theoretical and methodological past, as well as modern conditions of scientific communities, both from the former SFRY and other European and wider scientific communities and their paradigms.
\end{abstract}

Key words: scientific fund, concept, genre, theoretical approaches, classical genre theory, modern genre theory, classification, classification criteria, European tripartite classification of genres, Russian classification of genres, Yugoslav classification of genres, Anglo-American classification of genres.

* Associate Professor, dragan_tancic@yahoo.com

** Doctor of Sciences

*** Student

**** The paper was created within the scientific research work of the cientific research organization under the Agreement concluded with the Ministry of Education, Science and Technological Development number: 451-03-9 / 2021-14 / 200020 of February $5,2021$. 


\section{CONCEPTUAL DEFINITION OF GENRE}

Genre as a term in the existing scientific fund is used in political science, science of literature and language, as well as in other scientific fields and disciplines. The term genre indicates the common and special properties of specific forms of expression. Common properties, in form and content, make up the genre and distinguish it from other forms of expression. Therefore, without knowing the genre properties, we would not be able to make a classification, because without pointing out certain similarities and differences, the study could not be systematically and scientifically based.

The term genre is taken from the French language (genre, $n$ ) and means genus or species (lat. Gens) and it is used in this sense in other languages: German, English, Russian, Polish, Czech, Slovak, Bulgarian, Italian, Spanish. etc. In some dictionaries it is defined as "a certain form of literary works; style, manner" (Klaić 1962: 1600), and in other dictionaries and encyclopedias it has a somewhat broader meaning. In the former SFRY, it was translated as a genus or a genre, so that the term genre was often understood as a genre (literary genres: poetry, epics and drama), and sometimes a genre (a novella is a border genre, reportage is a literary-journalistic genre ...). The use of the term genre is common in the theory of literature when classifying literary works, as well as in the theory of journalism, when talking about journalistic forms (genres).

Genre is a general term used to denote a typical form of journalistic expression, and since the form depends on the topic and goal - it is a matter of content - composition and lexical - stylistic features. The genre is not determined by one, but by the whole set of characteristics, ie dominant features are taken into account. This does not deny that the character of the genre, since the art form is at the same time the art content, is significantly influenced by the individual abilities of the author.

There are several approaches in theoretical considerations of genres. According to the classical theory, genres by their nature not only differ from each other, but must also remain separated, ie they must not be mixed (Velek - Warren 1974: 281). According to another understanding, the so-called modern genre theory, the number of possible types is not limited, the authors are not "prescribed rules", and "traditional types can be mixed and given a new type (tragicomedy, for example)” (Velek - Warren 1974: 282). According to this understanding, genres do not remain eternally established, but change and develop with new circumstances, and new times bring new types and structures, and thus the notions about them change (novel and anti-novel, drama and antidrama, etc.).

Contemporary theoretical understandings in journalism have in mind the vitality of the genre and they are not tied to rigid definitions or. respect the 
existence of border genres, which is a justified approach, given that in practice there are no strict boundaries between genres close to areas, for example, between scientific works and literary-scientific genres and journalism. Therefore, with full right, back in the late sixties of the last century, Danilo Žlender points out that "journalistic genres are not and cannot be absolute values given once and for all" (Žlender 1967: 62), that forms of journalistic expression are something that does not is subject to a template, because "they represent a living and dynamic matter that is in the immediate process of change and a constant search for new, better, more adequate expressions ... (Žlender 1967: 64) Dušan Slavković believed that journalism is very little developed as a theoretical discipline, notices that in addition to "typically journalistic types", there are also genres that are not pure forms of journalistic expression (Slavković 1975: 127). Jevtović, Petrović and Aracki believe that in the theory of journalism it is generally accepted that the genre means "... a pattern that determines the form of content (the term is from the theory of literature), the ideal type, the category on which they are created, shaped, organized, connected, interpreted and different texts. Genres are characterized by a series of common structural-content features, formally-organizationally based and stylistically marked. In journalism, this implies interaction with the audience, a measure of communicativeness with which the content creates a certain meaning "(Jevtović et al. 2014: 115). These authors believe that genres develop a specific structural matrix by which facts are presented to the public in an interesting and creative way, in order to gain public attention, and therefore the role of journalists is to shape content in accordance with social needs and functions, respecting professional conventions. through the rhythm of the media, they become informally implicit rules, emphasizing that journalistic genres are determined by the media, function, form and content and always represent a part of social and political reality (Jevtović et al. 2014: 115-117). According to the definition from the Great Soviet Encyclopedia, a genre is "a community of structural-compositional properties specific to a given genre", which indicates its flexibility, because structural-compositional properties can change, and with them notions of genre, which does not set the journalistic type. as a petrified creation, similarities and differences between genres are already suggested, which can also permeate, but which are basically determined on the basis of dominant structural-compositional features (Životić 1979: 22). Russian authors understand the genre as a concept that is constantly evolving, and depending on the cognitive capabilities of society as a whole (genre is one of the means of understanding the world); second, with changes in ideas about the essence of the world itself; third, with technological transformations in the field of information delivery and processing. They believe that the process of genre development occurs within the internal transformations that take place within the boundaries of the information and communication system in all its 
connections and relationships. Scientific achievements within the natural sciences and humanities, advances in technical and technological development, led to the rupture of previous ideas about the world ("decanization - parting"), which resulted in the decanation of genres. The main processes in this context are: assimilation of journalistic creativity with other activities (for example, genres of letters and reports derived from the practice of business communication to journalism), interdependence and interaction of traditional genres (essay and commentary, essay and column, interview and essay, correspondence and article), a noticeable weakening of genre regulation, the disappearance of genre security caused by resistance to the canon (today many talk about information correspondence, analytical report, etc.). All this favored different approaches to the classification of genres ${ }^{1}$. According to EI Pronin: "The requirement of the genre is a condition of current social practice translated into the language of professional mastery that requires a message, whose typological structure is optimally adapted to the reality of social life", which means that everything dictated by social practice and published in the media can be considered a genre ${ }^{2}$. In journalism, interaction with the audience is also important, a measure of communicativeness with which content creates a certain meaning, which Bejzerman states: "texts mediate human action at a distance and help them become part of larger social institutions and practices, and genres provide means for and interaction" (Bazerman 2011).

\section{CLASSIFICATION OF JOURNALISTIC GENRES}

In the theory of journalism, there is a general agreement when defining the term genre, in the part that it means different types of journalistic forms of expression, but there is no general agreement with the classification. The theory of genres in the former SFRY was mostly dealt with by: Sergej Lukač, Mario Plenković, Slobodan Obradović, Danilo Žlender, Živan Mitrović, Dušan Slavković, Marin Mladenov, Dušan Đurić, Raško Jovanović, Mile Nedeljković, Zdravko Leković, Jovan Šćekić, Nenad Ristić, Radomir Zivotic, Neda Todorovic, Veselin Kljajic and others. It must be emphasized that a large number of them worked in journalism, and their theoretical works had a great experiential basis.

When it comes to the classification of journalistic genres in theory and practice, many scholars who deal with journalism as a special scientific discipline, approach them in different ways. Namely, it can be stated that, in the theory of

\footnotetext{
1 https://studme.org/74103/zhurnalistika/klassifikatsiya_zhurnalistskih_zhanrov [02.02.2018]. 
journalism, as well as in the theory of literature, there is no general agreement on this problem. In the previous subtitle, we pointed out that there are several approaches in theoretical discussions of genres, and we also mentioned two general approaches: classical and modern theories of genres. The issue of classification of genres is extremely complex, primarily because the criteria for classification are different. Genres are constantly changing and evolving, processuality, as a result and consequence of the development of overall social, technical and technological changes and other conditions in which various phenomena and processes occur and develop (such as media development, the emergence and development of the Internet, electronic media, social networks, etc.). and various classifications and interpretations were to be expected. When we talk about genres, we must keep in mind the fact that there are "borderline and transitional types" in literature, which may have led Croce to declare a complete denial of "the meaning of classification by genera and species." H. Markjevič, E. Štajger, J. $\mathrm{V}$. Goethe have a similar attitude. It is necessary to emphasize that there is a constant intertwining and permeation between literature and journalism, and that these areas and disciplines, to a large extent, exist on creativity, and yet, since it is about the arts, there are no boundaries between arts. (Životić 1993: 10).

According to a number of authors, one of the basic criteria for the classification of genres is the criterion of belonging to a medium. This medium can be daily, weekly or monthly press, radio, television, social networks, Facebook, etc., where they all have some general and special properties and means of expression, which is an essential factor for shaping content. In that context, we have the written word in the print media, the use of various illustrative materials, etc. On the other hand, on the radio, genres are shaped by the spoken word, stylistically different, with both sound and sound recordings being used in the presentation, in order to achieve authenticity. Although there are certain similarities between newspaper and radio genres, the difference or specificity of radio genres must be emphasized, which differ significantly in their structure, which is largely determined by the available means of expression. Namely, newspaper news with headlines and their parts, usually narrative, is not sufficiently suitable for radio news, which again must be short, clear and broadcast with or without announcement, usually in blocks, but can, with the intonation of the announcement, to be more convincing than written - newspaper news. Audio elements here significantly affect the representation of reality. Television summarizes audio and visual elements in the most objective picture of reality, represents the highest degree of persuasiveness and persuasion. The means of expression of television stations, as well as the means of radio, cannot be understood as an elementary application of technique, because for the presentation of documentary and authentic reality the creativity of a journalist is important, his creative invention. Television as a medium is realized through creative, professional, knowledgeable, 
artistic procedures, "design" and order of presentation of some information or information, and therefore it is claimed, not without reason, that television is the most influential medium, because it can provide the audience with a complete picture of reality. Otherwise, it is an indisputable fact, for example, that a news story read on the radio is still essentially a newspaper, just as a newspaper dash is read on the radio without the use of phonic means - still basically ie. essentially newspaper. This means that newspaper genres, regardless of the differences in their understanding in different countries, radio genres and television genres differ significantly from each other, and the differences are manifested in the structure, connection and creation of facts, style and language and application of technical and other procedures. It is all one whole, a presentation of reality and cannot be viewed partially, apart from the context of the whole. It is indisputable that e.g. an author with a written word appears in the newspaper genre; that in the radio genre appear: author or speaker with a spoken word, "living word" of the participants and sound and sound recordings, and that in the television genre are united and harmonized - the author with a spoken word (as an informant, interpreter and commentator), participants' "living words", sound and sound recordings and synchronized images (static or dynamic) which complete the image of reality. This means that if the medium is more complex and the authorship is "more collective", that is a sufficient reason for classifying genres according to the criteria of the media, as Radomir Životić pointed out (Životić 1993: 10). The same author believes that the second criterion for classifying genres is the author's relationship to reality. If the reality is factually, without emphasized subjective determination, it is a matter of purely journalistic genres, and if the reality is approached selectively, subjectively choosing ("passing it through the prism of personal vision") but not hurting reality - it is about introducing certain artistic procedures "Poetization of reality", where the journalist thus approaches the writer and the artist in general. Given the fact that there are no clear boundaries between journalism and art, because these two areas intersect, the quoted author believes that there are "borderline" or "hybrid" genres that are both, which means that both journalist and writer show "reality", there is only a difference in understanding and interpretation, ie. "Seeing" and the quality of reality. On the basis of such a relationship, journalistic-artistic genres appear, and we have borderline journalistic-literary genres (reportage, dash, humoresque, feuilleton, essay ...), but also radio-dramatic types (radioreportage, radio-dash, radio- drama, radio essay ...) and television genres that approach film art (TV reportage, TV dash, TV essay ...). This author emphasizes that the existence of borderline genres in journalism is no exception, just as there are border types between literature and science, and within literature there are border types (ballads, poems, romances, tragicomedy, elegy, short stories, etc.), which is consistent with modern aesthetics and poetics that accepts a flexible 
interpretation of genres, rejects the theory of pure forms and allows their mixing and the emergence of new species, which means that genres do not tolerate any patterns (Životić 1993: 12). Professor R. Životić then states the third criterion of classification, according to the content-formal properties, which according to him are the most grateful classification criteria for journalistic genres, because based on the attitude towards facts (whether we inform or discuss them), and how we shape them and with what intentions and in what structures we incorporate them we can classify genres into several groups. In this classification, the author emphasizes the structural-compositional features that are specific to specific forms of expression in which the themes, motives, language and style are reflected, and divides journalistic genres into:

1. "Informative: news (basic type news, interpretive news, rarity news, flash, antifiles, communiqués, short news, protocol news, photo news, news in a row, correction, denial ...), report, interview, survey, note, chronicle, statement, claim, in memoriam ...

2. Analytical: article, commentary, editorial, review, essay, review, discussion, sketch-essay ...

3. Journalistic and literary: reportage, dash, humorous article, caricature, kozerija, anecdote, feuilleton, journalistic story, portrait ...

4. Other genres and journalistic materials: caricatures (as art material), aphorisms, epigrams, leaflets, pamphlets, comics, etc. (Životić 1993: 12-13).

This author points out that the third group of genres is also called journalistic-publicistic genres, and that the supporters of this concept believe that journalism begins where thought begins, as if other genres can do without "thought", forgetting that argumentation in journalism is an essential factor. content, as well as that the structure of the presentation of facts may refer to a certain genre. The form of expression (monologue or dialogue) can also be taken as a classification criterion, and genres can be classified into monologues and dialogues (Životić 1993: 13). Also, below, the cited author cites length or brevity as possible classification criteria, although he points out that they are not reliable, but can be helpful in identifying genres (Životić 1993: 13). The presented and non-presented classification criteria according to the same author are conditioned by the media, and therefore the classifications of genres are very complex, because it is relatively easy to list some "differentia specifica" and thus a new classification of genres, and to this can be added the lack of professional and scientific terminology, so we can talk about a newspaper, literary or scientific article. For example, a survey can denote a journalistic genre (newspaper, radio and television), but it can also mean one of the techniques of the interrogation method. On the basis of the above, it can be concluded that the above-mentioned author puts emphasis on the content-formal criteria of classification, because they essentially significantly influence the formation of the genre - the form of expression. 
On the other hand, we will also present the classification of genres Jevtović, Petrović and Aracki (Jevtović et al. 2014: 117) from 2014, conditionally speaking, more modern ("fresher"), considering the criterion of years (Životić defined this classification in 1993, before 26 years). The mentioned authors believe that the theory of genres from the period of communism essentially relied on the patterns of classical court nonsense and literature. According to their understandings, "the establishment of a journalistic theoretical concept with genre classifications and definitions is a need of modern communication science" (Jevtović et al. 2014: 117). They state the tripartite division of journalistic genres, and as a basic criterion of classification they take fact, analysis (opinion, attitude) or description of experiences and expression of impressions and feelings, and on that basis they classify genres into:

- informative (factual),

- analytical, and

- fiction.

According to them, informative genres include: interview, news, report, press conference, press release and statement as a variation of report, interview. For the interview, they emphasize that it involves communication with sources of information in order to gather the necessary facts, and therefore in their theoretical approach, interview as a form is placed in the first place, as opposed to many theoretical approaches that usually begin with a chapter on news as the backbone of journalism (Jevtović i dr. 2014: 117).

Analytical journalistic genres include: commentary, article and critique, column, editorial as a variant of commentary, or review, note, social chronicle, online editions. They point out that caricature has gained special significance in modern journalism, and that its authors give a brilliant analysis of what is current by choosing a topic and a way of presenting reality, which is why they have included it in the analytical genre.

Fictional journalistic forms are: reportage, feuilleton, dash, note, anecdotes, kozery, etc. Then they state the classification made up of media criteria or. from the point of view of radio and television, these genres are divided according to communication participation into: monologues (news, report, statement, review, commentary, social chronicle); dialogical (interview, polemic, round table, microphone discussion, panel discussion), and polyphonic (reportage, survey). This classification is considered conditional, since in practice genres are often intertwined.

The authors are of the opinion that the stated (their "- author's note) tripartite classification of genres belongs to the so-called European point of view, which in their view is an attempt to introduce as many journalistic types and subtypes as necessary response to the requirements of journalistic practice. the same view is to some extent complemented by the French and German typologies 
of genres. We consider this attitude about the tripartite classification and connection with the European point of view to be wrong, considering the circumstance that their so-called tripartite classification, derived from the classification of genres set by Professor Životić back in 1993. A more accurate and appropriate statement would be that their classification of genres relies on the classification of Professor Životić and other Yugoslav authors from the period of the 1960s to the 1990s. The mentioned authors also state the classification of the French, who group the genres as follows:

- source information (multiple types of news);

- reports (reports, reports, notes);

- extended topics (analyzes, columns);

- external reviews (interviews, debates);

- comments (editorials, chronicles, critiques).

Then we have the classification from the German practice:

- news;

- reportage;

- article, and

- interview.

According to them, there are only two groups of genres in the Anglo-American classification:

- informative (news and reports in classic format), and

- analytical (interviews, columns, comments and similar types),

where, under the influence of the sensibility of the audience and the turbulent changes in the market of media products, the Anglo-American typology practically respects two basic forms:

- news and

- story.

The same authors also state the classification of genres in Russian journalism, according to which it is noticed that it is characterized by "vagueness of genre typology" as well as a strategic approach to the study of genres. According to the Russian classification, the following genres can be identified:

- informative (note, news, report, interview, information letter, mini interview, report, obituary);

- analytical (analytical report, memo, speech, comment, sociological summary, survey, monitoring, rating, review, research, review, forecast, experiment, letter, confession, recommendation, analytical press), and

- artistic journalism (essay, feuilleton, pamphlet, parody, satirical commentary, life history, legend, epitaph, epigraph, anecdote, joke and play) (Jevtović et al. 2014: 116-121). 
Considering the above statements of Jevtović and other co-authors on the classification of genres in other countries (from 2014), for comparison, we list the views of Professor Životić on these issues from 1993, as a criterion of scientific knowledge can not be the basis in science for perceptions of some authors, that previous scientific knowledge from several decades ago is not enough or that it is outdated, obsolete, etc.). Namely, Životić is of the opinion that in American theory these issues were not given much importance, but that the following forms were mentioned: news, interview (about news, opinion, personalities), group, press conference, commentary and editorial. In Italian theory, newspaper genres are: news, interview, commentary and editorial. In Czechoslovakia: journalistic and non-journalistic, graphic materials; journalistic are: news, article, reportage and feuilleton, and the news has subtypes (short, interpretive, paper, communiqué, interview, reportage, etc.) as well as article (informative, polemical, editorial, commentary, essay and reader's letters).

In Soviet theory, we find different systems of genres with various authors, with Životić emphasizing that the theory and practice of Soviet journalism is the closest to Yugoslav understandings due to linguistic, historical, national, ideological, artistic and cultural similarities. Thus eg in the Journalists' Handbook, Bogdanov and Vjazemski emphasize the ambiguity of the term genre, by which they understand journalistic or journalistic genres, citing from newspaper genres: chronicle (small form, thematically different, with or without title, but without supertitle); brief information (news with details, 10 to 30 lines); disseminated information (wider report on the event, with details, printed independently or in informative sections, 40 to 50 lines); interview (published in newspapers, magazines, radio and TV, and the following are: our interview, short interview, flash interview, interview of the day, guest of the week, round table discussion, conversation with an interesting man, collective interview, interview note, survey, and may be an interview to a reader's question); report (thematically diverse - assembly, conference, rally, sports event, and subtypes are: general, thematically with commentary, up to 100 lines); travel records (living image of reality); dash (topic narrow, one event or experience); internal postcard (informative genre, topic from the life of the city, area, country, figures are given and conclusions are drawn); reportage (informative-literal genre, interesting form, pictorial representation, literal expression, themes from reality, something new, which deserves more attention, typically, the length depends on the theme and meaning, and pictures and drawings can be found as well). Reportage is the most interesting and generally known genre; in the USSR it appeared with this inscription only since 1955, and the subtypes are: daily, from the scene, from the plenum, fantastic, short, lyrical, documentary, with pages of history, written 30 years ago, and the most important are: reports about the event, thematic and analytical); note (newspaper and magazine genre, published independently, 
and may be letters from readers); open letter; correspondence (letter); article (analytical genre of great importance, thematically different, and the subtypes are: directive, problematic, general, critical); editorial (ideologically colored genre); press review; review (similar to the article, and the subtypes are: literary, theatrical, film, concert, music); review (essay) with subtypes: content, plot, descriptive, portrait, problem, event, travel writing); feuilleton; pamphlet; parody (in prose or verse); epigrams (short, witty verses with a point, published with a caricature and a cartoon); stories, poems, short stories, poems, legends, lectures, etc. are published within the "genres of literal materials".

Considering the media, in the field of radio journalism, these authors emphasize the following genres: short information (news), reports, radio reports, radio sketches, radio feuilletons, letters, comments and lectures. They emphasize the importance of radio as a medium, its great listenership, diversity of audiences (listeners and illiterates), diversity of expression (music, speech, sound effects), selection of facts (minimum numbers and specialist terms), advantage of live words (sound recordings) in the function of documentary, a clear repetition of names, but not numerous. For them, radio composition is a difficult, complex, dramatic, lyrical or musical recording with the use of facts. Novels, lectures, sermons, etc. can also be heard on the radio. According to the same authors, television genres offer complete reality (speech, image and sound, music, photography, drawings), and a journalist is not obliged to just give a text, but also to write a synopsis with illustrations (background). From the genres they list: interview, round table, short information, TV note, TV report (event report, thematic report). TV essay, press review, lectures (with the use of pictures, maps, models), and other music and literal genres can be broadcast.

Životić states that Cherepakhov's (Problems of Genres in Journalism) emphasizes the study of genres both in theory and in practice, emphasizing that there are many misunderstandings, disagreements, etc. regarding that problem. According to Cherepakhov, information and journalism are two "related complexes", and newspaper genres are divided into informative and journalistic, where he insists on the complexity of genres, and from individual mentions: information, note, review, interview, reportage, report, review, article, letter, press review, letter, dash, feuilleton, pamphlet, etc. He emphasizes that not all topics should be formed in one genre, because each topic and each content requires an adequate form.

A group of authors in the monograph Mass Media in Socialist Society emphasizes that the genre is "a general, typical form of journalistic expression", and that its formation is conditioned by numerous causes: publication, goal, media, and that the genre is not determined by one, but by whole characteristics. Journalistic genres are divided into: reportage (note, reportage, report, dash), scientific-journalistic (letter, article, review), artistic-journalistic (review, feuilleton, 
pamphlet), dialogue (interview, journalistic dialogue), review, review science, literature, art, etc. In their opinion, the characteristics of individual genres would be the following:

- note (statement of fact, what, where, when it occurred, cause, summarized);

- reportage (obviousness, concreteness, compositional perfection; journalist dynamically presents what he saw and experienced; newspaper, radio and TV reportage);

- report (informative genre, reportage and scientific-journalistic);

- dash (artistic-publicist genre, fragment of reality, presence of the author);

- letter (scientific-journalistic genre, analytical);

- article (analytical, propaganda, types: editorial, theoretical-propaganda and problem);

- review (scientific-journalistic genre);

- artistic and journalistic genres (essay, feuilleton, pamphlet);

- interview (newspaper, radio, TV);

- survey-interview (press conference, round table, journalistic dialogue);

- review (newspaper, radio and TV);

- radio genres (reportage, commentary);

- television genres (TV review and TV documentary).

The collection Stylistics of Journalistic Genres (Moscow, 1981) deals with linguistic and stylistic features of problem genres: editorial, chronic information, reportage, correspondence, review, feuilleton and style of literary and artistic criticism. The analysis of style and language leads to the conclusion about the complexity, diversity and peculiarities of these genres depending on the type of publication, the author 's ability and critical experiences.

In G.V. Kuznetsov's book TV Journalist which discusses the choice of a competent interlocutor, the ethics of the interviewing journalist, the psychological basis of interviewing, viewers, etc., the author defines the interview as a free and focused conversation on a specific topic, and emphasizes the following forms of interviews: protocol interview (using official questions to get an official explanation of issues in the field of domestic or foreign policy) informative interview (present the person socio-psychologically, emotionally, emphasize human values), discussion - problem interview (different points of view on the same issue, exchange of views) and interview-survey (the aim of which is to get a public opinion on specific questions asked by different interlocutors; everyone is asked only one and the same question). According to the presented criteria, what is an interview, this fifth type of interview, the fifth subtype is debatable and confusing, because a survey is a survey, it has its own structural-compositional characteristics, and does not fit into the interview in any way (no competent person is chosen, no more questions are asked, no conversations, and the respondent may 
be a bystander who does not have to answer, etc.). So, a television interview poll is not a subtype of a TV interview.

Životić rightly warns that omissions of this type in the classification of genres are also possible in countries with more extensive scientific and professional literature, so that there are certain contradictions when it comes to e.g. about reportage and other borderline or debatable genres. He points out that it is interesting that the classifications of genres do not mention a fictional interview, but a newspaper one where one usually writes about a person and the art of answering from various occasions to new contexts, and television is mounted from visual, sound and tonal elements from different contexts; the picture and answers are authentic, and everything else is made up. Both types of interviews are usually humorous or satirical (Životić 1993: 13-16).

One of the Russian authors, in the middle of the XX century, V.D. Pelt proposed a relatively rigid classification system where genres were divided into three groups: informative (note, report, interview, report), analytical (correspondence, article, review, commentary), artistic and journalistic (essay, sketch, feuilleton, pamphlet), essay). The classification was based on three criteria: subject, function and method. The form and content of the publication are not included in the system of genre characters. When it became clear that changed social and professional practices brought about major changes in the nature of domestic media activities, new classifications emerged, proposed by E. I. Pronin, V. T. Tretiakov, G. V. Lazutina, S. S. Raspopova, A. A. Tertichni, and others. ${ }^{3}$

According to E.I. Pronin: "Journalistic genres should be compared in two parameters: first, with a substantial approach to presenting the real process of social practice, and second, by setting a goal at the level of understanding the subject of presentation." Essentially here we have two properties - the subject of the image and the function of the image of the subject as the target setting of the author. From the intersection of the study subject and the author's goal setting, a proposed classification emerges, which includes such texts as "confirmation", "motto", "questionnaire", "signal" and "official statement" as independent genres - a total of 36 subjects. ${ }^{4}$ G. V. Lazutina and S. S. Raspopova identify three criteria for the classification of genres: "object-specific diversity of reality"; "Polyfunctionality of journalism" and "lability of the generative model" and accordingly conclude: "Studying journalistic practice at the current stage of its development allows us to discover six types of journalistic creativity, each of which appears as a specific group of models and a corresponding set of specific activities." These six types of creativity are journalism, problem-analytical journalism,

3 https://studme.org/74103/zhurnalistika/klassifikatsiya_zhurnalistskih_zhanrov [02.02.2018].

4 Ibid. 
laughter journalism, cultural and educational journalism, and interactive journalism. In problematic-analytical journalism, the authors distinguish the following genre models: correspondence, article, personalized and business correspondence, commentary, review. They talk about a special format of correspondence - journalistic investigation, about an analytical report as a type of personalized correspondence. In a series of genre models of the texts of the sketches by G. V. Lazutin and S. S. Raspopov, they consider the sketch, the everyday story, and the essay. They include humorous journalism, a joke, an anecdote, a satirical note, a pamphlet. In the category of cultural and educational journalism, the announcement, summary, review, review, artistic article, creative portrait were mentioned. Among the genre models of interactive texts are a review of letters, an answer to a question, a report, a literary record, an interview, a conversation. It is noticed that traditionally recognized genres in this system that modify journalistic texts coexist with reality analysis techniques and forms of presentation of material. The proposed classification does not facilitate a theoretical understanding of the issue of genre classification, and as such cannot help journalists in practical creation ${ }^{5}$. V. T. Tretiakov proposed a simpler classification of genres in his book How to Become a Journalist, namely: interview, information, reports, article and four official ones: photograph, subtext, image, title. A. Tertichni in his book Genres of Periodicals points out that in journalism there are "three main ways of presentation - supporters of the classification of genres within the traditional scheme: informative, analytical, artistic and journalistic." So, the list of facts: information note, informative correspondence, informative report, informative interview, answer to the question, reportage, obituary. List of analytical: analytical report, analytical correspondence, analytical interview, analytical survey, interview, comment, sociological summary, questionnaire, grade, review, article, journalistic investigation, review, media review, forecast, version, experiment, letter, acknowledgment, recommendation ( response), analytical press release. Artistic and journalistic genres: sketch, feuilleton, pamphlet, satirical commentary, everyday history, legend, epigraph, anecdote, joke, play. The fact that genres are transferred from one classification group to another does not bother the author. Like the fact that, say, a note answers the questions, "What's going on? Where? When? Why? How?". In any case, they serve to describe a phenomenon, an event, an action, a verdict that became known to a journalist. In addition to the above, the question arises: If informative and analytical genres answer the same questions, then why divide them into groups? In addition, it is difficult to recommend journalistic genres, to consider everything that is published on a journalistic page. Groups of contemporary domestic publications offer audiences horoscopes, crossword puzzles, weather reports, notices, greetings, obituaries,

5 Ibid. 
advertising and other announcements (information and business unit), stories, poems, reproductions, excerpts from films and epic works of large forms (literature and art), advertising and PR materials, business information (advertising and business unit). This is not journalism in its optimal expression. These are publications that have acquired certain journalistic characteristics due to their presence on the journalistic page. Thus, as an example, Konstantin Simonov's song "Wait for me", published in Pravda at the beginning of 1942, a purely personal message of a husband and wife, turned into a journalistic document of the era. The text of the letter was cut from the newspaper pages, remade and kept as a talisman - amulet. We also have Alexander Tvardovsky's poem "In the Next World”, published in Izvestia 1962, which criticized bureaucratic practices, had a significant journalistic role, and was a specific signal to a large readership: there are problems that the authority that allowed the satirical edition remembers. Another example from the period 1920-1930 is given, when the methods of scientific propaganda were widely used in the Soviet press, that is well-known scientists were given a lot of space where they talked about modern scientific achievements in chemistry, physics, medicine, etc. The sheets of any publication reflect the given time and objectively help to understand the total time that prevails in the society, and these are the actual documents of the time, and that is their journalistic significance. One must always keep in mind the circumstance that journalistic texts cannot be independent, both in terms of content and form, ie. by independence and the journalistic genres themselves.

According to Dubravka Valić Nedeljković, "media genres are divided into two general groups, in relation to the type of media practice: monologue and dialogue. Monological journalistic author's texts are: news, report, note and commentary (review, obituary, dash). Dialogue is the interaction of journalists with one or more interlocutors: statement, survey, panel discussion, controversy, conversation, contact-show, classic media interview in which the interview model is used. Monological genres involve gathering information from sources, going to events, and reporting from the scene either in the form of news (basic form) or in the form of reports. In the texts they write, journalists have answers to five imaginary questions of their audience: who, what, when, where, how (why) happened. Notes and comments are more demanding journalistic forms and require, in addition to knowledge of events, a better knowledge of the social phenomena that caused them. Commentary is the only genre in which journalists are obliged to express their position, or the position of the media house for which they write about a social phenomenon or event. In doing so, they can find themselves in the role of interpreter, author, or responsible person (principal). As a rule, commentators are journalists who combine all three functions with the fact that they can speak on their own behalf, but with respect for the editorial policy of the media house in which they work, regardless of whether they agree 
with it as a private person or not. Other monologue genres are not marked in relation to the listed functions". ${ }^{6}$ The mentioned author emphasizes that "dialogic forms have developed with the advent of electronic media. He worked and discovered the interview as a dialogical form in the full sense of the word. Dialogue forms are a real media expression, but also a challenge for radio and television. Just as news in monologue forms is the basis from which all others develop and which is contained in everything else, so in dialogical forms for all genres, more or less complex, the basis is interview."

The difference or lack of general agreement in perceptions of genres is a consequence of the genesis and development of literature and journalism. Thus, A. Hauser explains the conditions for the emergence of classical literary genres and their syncretic character, and by enumerating literary genres - he proves their interconnectedness (Hauser 1962). B.V. Tomaševski claims that there are general characteristics of the species, that the species cannot be logically and safely classified as historical categories, but clearly points out that the characteristics of the species are in the internal structure, that they are procedures that adjust the composition of the work and that they are dominant (Tomaševski 1972: 227-231). Both R. Velek and O. Voren see the characteristics of the species primarily in form as the sum of available aesthetic means (Velek - Voren 1974: 278). R. Dimitrijević classified literary and journalistic genres, and he saw the characteristics of the genre in content and form, ie. "In the substantive, internal features of a work.” D. Živković (Živković 1974: 123-124) and M. Solar (Solar 2005: 115-117) have a similar opinion.

M. Milos understands the genre more broadly, as a "written, audio or pictorial communication of political current, socially significant, new or re-established, documentary titling of events or ideological expressions" and then states: "Journalistic type (phenomenon) is a linguistic reproduction of events the prism of the creative subject and his attitude towards it, transformed, reproduced in another substance - linguistic "(Miloš 1972: 16). MS Cherpakhov understands the genre much more concretely, and he claims that the genre must have certain constant properties that are repeated in the "essence and structure of form" (ie content and form), and given that journalism reflects life in its complexity "does not exist and there can be no single interpretation of the term genre, since different areas of the art of literary creation produce completely different genres according to their initial features"(Cherpahov 1973: 26). Zlender notices the connection between literature and journalism and rightly points out that genres cannot be absolute values because "the peculiarities of the press of those countries" are built into them. The thesis is very easy to prove on the example of a report. What is meant by this genre in our country can be called "report" or "article"

6 http://novinarska-skola.org.rs/vodic/zanrovi/Novinarski\%20zanrovi.pdf [10. 08. 2018].

7 Ibid. 
in other countries; that's how American journalists understood the term "reporting" as meaning everything a reporter published.

In addition to many other classifications of genres and different classification criteria, the characteristic classification criteria for the former SFRY are given, because even now these are in fact the basic starting points, someone would say "paradigm" for current, modern or current conditions in theory and practice. journalism.

\section{CONCLUSION}

Based on the above, we can conclude that the term genre is used primarily in political science, as well as the science of literature and language and their scientific disciplines. This term emphasizes some common and some special features, both in form and content, which distinguishes the genre from other forms of expression. Based on the insight into the scientific fund, it is indisputable that there is no general agreement when defining the term genre in many authors, which is not disputable, given that many authors belong to various scientifictheoretical and methodological directions. In that context, there is a difference in the classification of genres and differences in the choice of classification criteria, and consequently the existence of different theories and approaches, starting from European to Soviet, Russian, Anglo-American, Yugoslav and others. Given these similarities and differences, it is indisputable that the presence of different theories, approaches, paradigms, can and must continue to influence different theoretical and methodological approaches to defining genres and their classification criteria.

\section{REFERENCES}

Bazerman 2011: Ch. Bazerman. „Genre as Social Action“, In. J. Gee \& M. Handford (Eds.), Routledge Handboook of Discourse Analusis. London: Routledge.

Čerpahov 1973: M. S. Čerpahov. „Publicistički žanrovi. Žanrovi sovjetske štampe“. Informisanje u praksi, br. 3/1973, 26.

Dimitrijević 1968: R. Dimitrijević. Teorija književnosti sa primerima: lirska i epska poezija. Beograd: Savremena škola.

Hauzer 1962: A. Hauzer. Socijalna istorija umetnosti i književnosti. Beograd: Kultura.

Jevtović i dr. 2014: Z. Jevtović, R. Petrović, Z. Aracki. Žanrovi u savremenom novinarstvu. Beograd: Jasen.

Klaić 1962: B. Klaić. Riječnik stranih riječi, izraza i kratica. Zagreb: Zora.

Miloš 1972: M. Miloš. „Novinarski žanrovi“. Informisanje u praksi, 4/1972, 16.

Slavković 1975: D. Slavković. Osnovi novinarstva i informisanja. Beograd: Radnička štampa.

Solar 2005: M. Solar. Teorija književnosti. Zagreb: Školska knjiga.

Tomaševski 1972: B. V. Tomaševski. Književne vrste. Teorija književnosti. Beograd: SKZ. 
Velek-Voren 1974: R. Velek, O. Voren. Teorija književnosti, II izdanje. Beograd: Nolit. Živković 1974: D. Živković. Teorija književnosti. Beograd: Naučna knjiga.

Životić 1979: R. Životić: Posleratna reportaža i njene stilske odlike. Gornji Milanovac: Dečje novine.

Životić 1993: R. Životić. Novinarski žanrovi: štampa, radio, televizija, knjiga I. Beograd: Institut za novinarstvo.

Žlender 1967: D. Žlender. „Žanrovi u našoj štampi“. Novinarstvo, 1/1967, 62.

\section{SOURCES}

http://novinarska-skola.org.rs/vodic/zanrovi/Novinarski\%20zanrovi.pdf [10.08.2018].

https://studme.org/74103/zhurnalistika/klassifikatsiya_zhurnalistskih_zhanrov [02.02.2018]. 
Араган Һ. ТАНЧИТ

ААема ЧОАИТ

Мидија А. ТАНЧИЋ

\section{ПРОБАЕМИ НАУЧНОГ АЕФИНИСАҢА И КААСИФИКАЦИЈЕ ЖАНРОВА У НАУЧНОМ ФОНАУ}

\section{РеЗИме}

Проблеми научног дефинисања и редефинисања појмова, следствено томе, у складу са темом овог научног рада, су и проблеми научног дефинисања појма жанр и класификације жанрова у научном фонду. Аефинисање појма жанр је битан научно-сазнајни процес, којим се стичу битне одреднице самог појма, које имају дефиниендум и дефиниенс; преАметну и саАржајну вреАност, којим се обухвата целина предмета а посебно критеријуми класификације појма. У овом раАу, генетичким дефиницијама посебно ћемо обухватити генезу и развој појма жанр и научно-теоријским и методолошким правцима различитих наука и научних Аисциплина. По временским и територијалним оАреАницама, овим радом смо обухватили ближу научно-теоријску и методолошку прошлост, као и савремене услове Аеловања научних зајеАница, како са простора бивше СФРЈ, тако и Аругих европских и ширих научних заједница и њихових парадигми.

Kьучне речи: научни фонА, појам, жанр, теоријски приступи, кмасична теорија жанрова, модерна теорија жанрова, класификација, критеријуми класификације, европска трипартитна класификација жанрова, руска класификација жанрова, југословенска класификација жанрова, англоамеричка класификација жанрова.

РаА је преАат 20. Аецембра 2021. године, а након мишњења рецензената, оАмуком оАговорног уредника Башичине, одобрен за штампу. 